\title{
The moment-gradient factor in lateral- torsional buckling of castellated steel beams under mid-span concentrated load
}

\author{
MOHAMED A. DABAON \\ Prof. of Structures and Steel Bridges, Structural Engineering Dept., Tanta University, Tanta, \\ Egypt. \\ E-mail:m_dabaon@yahoo.com \\ MAHMOUD H. EL-BOGHDADI \\ Assoc. Prof. Structural Engineering Dept., Tanta University, Tanta, Egypt. \\ E-mail:mhboghdadi@yahoo.com \\ O. F. KHAROOB \\ Assoc. Prof. Structural Engineering Dept., Tanta University, Tanta, Egypt \\ E-mail: omnia_m102010@yahoo.com \\ AZA MOHAMED ELAGAMEY \\ M. Sc. Student, Faculty of Engineering, Structural Engineering Dept., Tanta University, \\ Tanta, Egypt \\ E-mail: Aza_mohamed@yahoo.com
}

\begin{abstract}
increasing the value of $\left(\mathrm{h}_{\mathrm{o}} / \mathrm{H}\right)$ and decreasing the value of $\left(\mathrm{h}_{\mathrm{w}} / \mathrm{t}_{\mathrm{w}}\right)$.On the other hand, the influence of $\left(\mathrm{b}_{4} / \mathrm{h}_{\mathrm{w}}\right)$ has noticed effect on the value of $\mathrm{C}_{\mathrm{b}}$ especially in big opening. The studies extended to investigate the non-compact sections to compare the values of $\mathrm{C}_{\mathrm{b}}$ in the case of compact and non-compact sections with the predicted design codes. It is found that, the values of $C_{b}$ in short spans have lower values than the predicted design codes. Hence, simplified empirical Equations ${ }_{\text {of }} \mathrm{C}_{\mathrm{b}}$ are proposed for compact and noncompact section based on the best fit of the values of $\mathrm{FE}$.
\end{abstract}

\section{Introduction}

The benefit to use beams with web opening in the building is to allow services ducts to pass. Castellated beams are varieties of girder with generally circular or rectangular or hexagonal web openings, distributed along the beams with regular intervals. The process of built-up castellated beams is cutting the web in zigzag pattern along its centerline and then rejoining the two halves by welding. This process leads into an increase in bending capacity and a reduction of the weight of constructions.
In this paper, the elastic lateral stability of castellated steel beams with hexagonal opening under concentrated load is conducted. 3D elastic finite element (FE) model is performed by using FE software package ABAQUS. A parametric study is made on compact sections to investigate the effect of the slenderness ratio of web $\left(h_{w} / t_{w}\right)$, the size opening $\left(h_{o} / H\right)$,spacing of opening $\left(\mathrm{b}_{4} / \mathrm{h}_{\mathrm{w}}\right)$ and slenderness ratio of flange $\left(b_{f} / t_{f}\right)$, on the behavior of momentgradient factor $\left(C_{b}\right)$.The results indicate that by increasing the values of $\alpha_{L B}$ parameter the values of $\mathrm{C}_{\mathrm{b}}$ decrease. In addition, the values of $C_{b}$ decrease with

the beam allowing this type of beams to be used for medium to long spans constructions. Many researchers investigated the non-linear behaviour of castellated steel beams using experimental and analytical studie [1-5]. Zirakian and Showkati [1] tested six fullscale castellated beams for studying the distortional buckling behaviour. HOSAIN and SPEIRS [2] performed experimental program on 12 simply supported castellated steel beams to study the effect of the 
geometry of opening on different modes of failure and ultimate strength of such beams. On the other hand, Showkati et al. [3] focused on the effect of exciting elastic braced systems on the behviour castellated beams. Based on analytical study Ellobody [4] investigated a parametric study taking the effect of different cross-section geometries, beam length, steel strength and non-dimensional slenderness on the failure loads and the interaction of buckling modes in castellated steel beams. Soltani et al. [5] used nonlinear FE analysis to investigate the ultimate behavior of steel castellated beams with hexagonal and octagonal openings. Mohebkhah [6] studied the moment-gradient factor in lateral-torsional buckling on inelastic castellated beams taking the effect of slenderness parameter in consideration. On the other hand, Sweedan [7] proposed an empirical formula of a moment modification factor for I-shaped cellular beams related to lateral buckling (LTB and LDB) modes only. The above literature review indicated that the most studies concentrated on the nonlinear behaviour of castellated beams and very limited studies were studied the elastic later-torsional buckling of that beams. Hence, the contributions of the current paper can be summarized as follows.

- Giving more information about the effect of key parameters related on the geometry of castellated beams with compact sections on the behavior of momentgradient factor $\left(\mathrm{C}_{\mathrm{b}}\right)$.

- Discussing the values of $\mathrm{C}_{\mathrm{b}}$ in the case of compact and non-compact sections compared with the predicted design codes.

- Suggesting simplified empirical equations of $\mathrm{C}_{\mathrm{b}}$ for compact and non-compact section based on the best fit of the values of FE.

\section{Finite element modeling}

\subsection{Description of the model}

The numerical program was conducted herein on full-size hexagonal castellated steel beams using the ABAQUS finite element program (version 6.8) [8]. Typical FE model was illustrated in Fig. 1 which defined all the dimensions of the current study beams. To study the $\mathrm{C}_{\mathrm{b}}$ factor of these beams, three hundred eighty six finite element models were created on compact sections according to Euro code 3[9] for the two cases of loads; pure moment and mid-span concentrated loads. Another two hundred and seventy six finite element models were conducted on non-compact sections according to Euro code 3[9] for the two cases of loading. The considered cross-sections of the web for compact and non-compact sections defined by $\mathrm{h}_{\mathrm{w}} / \mathrm{t}_{\mathrm{w}}$ values vary between ( 35 to 85 ) and (87 to 144), respectively. Also, the flange crosssection of compact and non-compact sections were defined by $\left(b_{f} / t_{f}=11,13\right.$ and 14) and $\left(b_{f} / t_{f}=13\right.$ and 14$)$, respectively. The hole size of openings were characterized by $\left(\mathrm{h}_{\mathrm{o}} / \mathrm{H}=0.3,0.5\right.$ and 0.8$)$ and the values of $b_{4} / h_{w}$ were $1,1.5$ and 2 for the compact and non-compact sections. The spans of the beams were varied between ( 3 to $10 \mathrm{~m}$ ) with increasing of (1m ) to include the short, medium and long spans. The boundary conditions of the beams were simply supported at the end sections. S4R element characterizes with six degrees of freedom per node was used in the model. Mesh size of $10 \mathrm{~mm}$ was considered after many trials to get the accurate results. The steel material has been modelled as linear elastic material with Young's modulus $E_{0}=200 \mathrm{GPaand}$ Poison's ratio of 0.3 .

\subsection{Verification of the FE model}

To verify the performance of the $3 \mathrm{D}$ FE model, a span of $(\mathrm{L}=3$ to $10 \mathrm{~m})$ with 


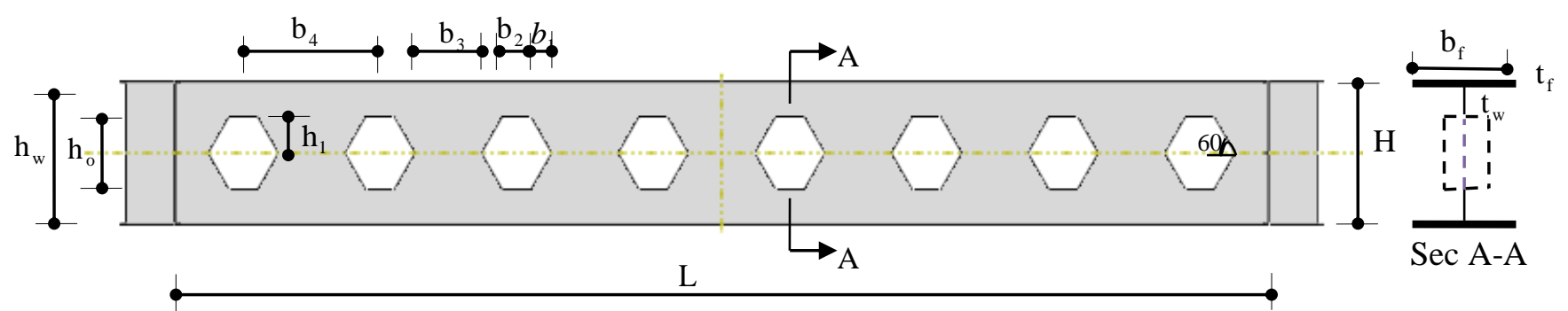

Fig.1: Dimensions of a castellated steel beams with hexagonal opening

$\mathrm{b}_{\mathrm{f}}=150 \mathrm{~mm}, \mathrm{t}_{\mathrm{f}}=10.7 \mathrm{~mm}, \mathrm{~h}_{\mathrm{w}}=278.6 \mathrm{~mm}$,

$\mathrm{t}_{\mathrm{w}}=7.1 \mathrm{~mm}, \mathrm{H}=300 \mathrm{~mm}$, is used to conduct

$$
\begin{aligned}
& \mathrm{G}=\frac{E}{2(1+v)} \\
& \mathrm{I}_{\mathrm{x}}=\frac{1}{12}\left[\mathrm{~h}_{\mathrm{w}} \mathrm{t}_{\mathrm{w}}{ }^{3}+2 \mathrm{t}_{\mathrm{f}} \mathrm{b}_{\mathrm{f}}{ }^{3}\right]
\end{aligned}
$$

to identify their critical moment $\mathrm{M}_{\mathrm{o}-\mathrm{cr}}$

values that correspond to the lateral torsional buckling mode.

The verification firstly was made on solid simply supported beams subjected to uniform end moments by evaluating the critical buckling moment. The results of FE were compared with the analytical critical buckling moment $\mathrm{M}_{\mathrm{o}-\mathrm{cr}}$ given by Ref. [10] as given below. Sample of the results were summarized in Table 1.

$\mathrm{M}_{0-\mathrm{cr}}=\frac{\pi}{\mathrm{L}} \sqrt{\mathrm{EI}_{\mathrm{y}} \mathrm{C}_{1}\left(1+\frac{\mathrm{C}_{2}}{\mathrm{C}_{1}} \frac{\pi^{2}}{\mathrm{~L}^{2}}\right)}$

Where $\mathrm{L}$ is the unbraced span of the beam and $I_{y}$ is the minor - axis moment of inertia of the cross- section. In Eq. (1), $\mathrm{C}_{1}$ and $\mathrm{C}_{2}$ are the torsional and warping rigidities, respectively; see Eq. 2 and 3.

$\mathrm{C}_{1}=\mathrm{GJ}$

$\mathrm{C}_{2}=\mathrm{EC}_{\mathrm{W}}$

Where $\mathrm{G}$ is the shear modulus of elasticity, $\mathrm{J}$ is the torsional constant the cross section, $\mathrm{E}$ is Young's modulus of elasticity and $\mathrm{C}_{\mathrm{w}}$ is the warping torsional constant of the cross- section.

$$
\begin{aligned}
& J=\sum \frac{b t^{3}}{3} \\
& C_{w}=\frac{t_{f} b_{f}{ }^{3} h^{2}}{24}
\end{aligned}
$$

The mean values of $\mathrm{M}_{\mathrm{cr}-\mathrm{FE}} / \mathrm{M}_{\mathrm{o}-\mathrm{cr}}$ was 1.03 with stander deviation was 0.0073.Other verification was made on simply supported castellated beams subjected to uniform end moments; see Fig.1. The results of the quantitative comparison between analytical solutions and finite element predictions were summarized in Table 2 as a sample of results. The mean values of $\mathrm{M}_{\text {cr-FE }} / \mathrm{M}_{\mathrm{o}-\mathrm{cr}}$ was 1.02 and its stander deviation was 0.011 .

$$
\begin{aligned}
& \mathrm{M}_{0 \text {-cr }}=\frac{\pi}{\mathrm{L}} \sqrt{\mathrm{EI}_{\mathrm{y}(\text { net })} \mathrm{C}_{1}\left(1+\frac{\mathrm{C}_{2}}{\mathrm{C}_{1}} \frac{\pi^{2}}{\mathrm{~L}^{2}}\right)} \\
& \mathrm{I}_{\mathrm{x} \text { (net) }}=\frac{1}{12}\left[\left(\mathrm{~h}_{\mathrm{w}}-\mathrm{h}_{\mathrm{o}}\right) \mathrm{t}_{\mathrm{w}}{ }^{3}+2 \mathrm{t}_{\mathrm{f}} \mathrm{b}_{\mathrm{f}}{ }^{3}\right] \\
& \mathrm{J}_{\text {net }}=\frac{2}{3} \mathrm{~b}_{\mathrm{f}} \mathrm{t}_{\mathrm{f}}{ }^{3}+\frac{1}{3}\left(\mathrm{~h}_{\mathrm{w}} \mathrm{t}_{\mathrm{w}}{ }^{3}-\mathrm{h}_{\mathrm{o}} \mathrm{t}_{\mathrm{w}}{ }^{3}\right)
\end{aligned}
$$

Hence, the results of verifications indicated a good agreement between the FE and the analytical method.

\section{Results of FE}

\subsection{General}

In this part, the influence of beam geometry on the moment gradient factor with the parameter $\alpha_{\mathrm{LB}}$ given in Eq. 11 was discussed. Firstly, compact sections were conducted with various parameters as described in section 2.1 to investigate there effects on the moment gradient factor. Secondly, the study was directed to compare the values of $\mathrm{C}_{\mathrm{b}}$ with the predicted codes. Then, the study was extended to 
investigate the effect of non-compact sections on the values of $C_{b}$.

$\alpha_{\mathrm{LB}}=\frac{\pi}{\mathrm{L}} \sqrt{\frac{\mathrm{C}_{2}}{\mathrm{C}_{1}}}$

were given previously in $\mathrm{C}_{1}$ and $\mathrm{C}_{2}$ Where Eqs. 2 and 3.

\subsection{Effect of $\left(h_{o} / H\right)$ ratio}

Figs. 2(a) and 2(b) show the relationships between $\mathrm{C}_{\mathrm{b}}$ coefficient and $\alpha_{L B}$ parameter with $\left(b_{f} / t_{f}=14.02\right)$ and $\left(b_{4} / h_{w}=1\right)$. From the results it can be concluded that by increasing the values of $\alpha_{L B}$ the values of $\mathrm{C}_{\mathrm{b}}$ decreases. Also, the values of $\mathrm{C}_{\mathrm{b}}$ decrease with increasing the ratio of hole size. In addition, for the web plates with higher hole size $\left(h_{o} / H=0.8\right)$ it can observe a clear reduction in the value of $\mathrm{C}_{\mathrm{b}}$ especially for high value of $\alpha_{L B}$.

Figs. 3(a) and 3(b) present the relationships between $C_{b}$ coefficient and $\alpha_{L B} \quad$ parameter with $\left(\mathrm{b}_{\mathrm{f}} / \mathrm{t}_{\mathrm{f}}=14.02\right)$ and $\left(b_{4} / h_{w}=2\right)$. General trend was observed in the figure the increasing of the values of $\alpha_{L B}$ causes decreasing in the $\mathrm{C}_{\mathrm{b}}$ values. On the other hand, by comparing between Fig. 2 and Fig. 3 it can be found that the increasing of the spacing of opening to the value of $\left(b_{4} / h_{w}=2\right)$ has no effect for the different hole size on the reduction of $\mathrm{C}_{\mathrm{b}}$.

\subsection{Effect of $\left(h_{w} / t_{w}\right)$ ratio}

Fig. 4 shows the relationships between $\mathrm{C}_{\mathrm{b}}$ coefficient versus $\alpha_{L B}$ parameter for section with $\left(\mathrm{b}_{\mathrm{f}} / \mathrm{t}_{\mathrm{f}}=14.02\right), \quad\left(\mathrm{b}_{4} / \mathrm{h}_{\mathrm{w}}=1\right)$, $\left(\mathrm{h}_{\mathrm{o}} / \mathrm{H}=0.3\right)$ and $\left(\mathrm{h}_{\mathrm{o}} / \mathrm{H}=0.5\right)$ as a sample of results. The results indicated that the value of $\mathrm{C}_{\mathrm{b}}$ decreases with increasing the value of $\alpha_{L B}$. Also, for all hole size the value of $\mathrm{C}_{\mathrm{b}}$ increases with increasing the value of $\left(\mathrm{h}_{\mathrm{w}} / \mathrm{t}_{\mathrm{w}}\right)$.

\subsection{Effect of $\left(b_{4} / h_{w}\right)$ ratio}

Figs. 5 and 6 illustrate the relationships between $\mathrm{C}_{\mathrm{b}}$ coefficient and $\alpha_{L B}$ parameter for $\left(b_{\mathrm{f}} / \mathrm{t}_{\mathrm{f}}=14.02\right),\left(\mathrm{h}_{\mathrm{o}} / \mathrm{H}=0.5\right)$ and $\left(\mathrm{h}_{\mathrm{o}} / \mathrm{H}=0.8\right)$, respectively. It was observed that with increasing the spacing between the opening $\left(b_{4} / h_{w}\right)$ the value of $C_{b}$ increases. This increase is clear observed in the high size opening $\quad\left(\mathrm{h}_{\mathrm{o}} / \mathrm{H}=0.8\right)$ than the lower $\left(h_{\mathrm{o}} / \mathrm{H}=0.5\right)$. Hence, it can be concluded that the influence of $\left(b_{4} / h_{w}\right)$ was notice in the high size opening.

\subsection{Effect of $\left(b_{f} / t_{f}\right)$ ratio}

Fig. 7 shows $\mathrm{C}_{\mathrm{b}}$ coefficient versus $\alpha_{L B}$ parameter relationships for $\left(\mathrm{b}_{4} / \mathrm{h}_{\mathrm{w}}=1\right)$ and $\left(h_{\mathrm{o}} / \mathrm{H}=0.5\right)$. From the fig. 7 it can be seen that by decreasing the slenderness ratio of flange $\left(b_{f} / t_{f}\right)$ the value of $C_{b}$ decreases.

\section{The moment gradient coefficient $\left(C_{b}\right)$ for hexagonal castellated steel beam with codes.}

In this section, a comparison between the results of $\mathrm{C}_{\mathrm{b}}$ from $\mathrm{FE}$ for the previous compacted sections and additional noncompact sections presented in Figs. 8 and 9 were created to investigate the effect of various types of cross-sections on the values of $\mathrm{C}_{\mathrm{b}}$ in all ranges of spans. For the compact sections it was found that the values of $\mathrm{C}_{\mathrm{b}}$ were different from the predicted code; see figures from 2 to 7 . The same observation was obtained for the noncompact sections with different values of $\mathrm{C}_{\mathrm{b}}$ as can be seen in Figs. 8 and 9. Hence, in this section two simplified new equations were suggested for the compact sections and non-compact sections with respect $\alpha_{L B}$ parameter as a variable function. Eqs. 12 and 13 illustrate the proposed equations of $\mathrm{C}_{\mathrm{b}}$ for the compact and non-compact sections, respectively. By comparing the results of $\mathrm{C}_{\mathrm{b}}$ from the 
Table 1: Comparison between finite element and theoretical buckling moments for solid beams

\begin{tabular}{|c|c|c|c|c|c|c|c|c||}
\hline $\begin{array}{c}\mathrm{H} \\
{[\mathrm{mm}]}\end{array}$ & $\begin{array}{c}\mathrm{b}_{\mathrm{f}} \\
{[\mathrm{mm}]}\end{array}$ & $\begin{array}{c}\mathrm{t}_{\mathrm{f}} \\
{[\mathrm{mm}]}\end{array}$ & $\begin{array}{c}\mathrm{t}_{\mathrm{w}} \\
{[\mathrm{mm}]}\end{array}$ & $\begin{array}{c}\mathrm{L}_{[\mathrm{mm}]} \\
{\left[\begin{array}{c}\mathrm{h}_{\mathrm{w}} \\
{[\mathrm{mm}]}\end{array}\right.}\end{array}$ & $\begin{array}{c}\mathrm{M}_{\text {cr-FE }} \\
{[\mathrm{kN} . \mathrm{m}]}\end{array}$ & $\begin{array}{c}\mathrm{M}_{\text {o-cr }} \\
{[\mathrm{kN} . \mathrm{m}]}\end{array}$ & $\mathrm{M}_{\text {cr-FE }} / \mathrm{M}_{\text {o-cr }}$ \\
\hline \hline 300 & 150 & 10.7 & 7.1 & 2000 & 278.6 & 475.0 & 469.10 & 1.01 \\
\hline 300 & 150 & 10.7 & 7.1 & 3000 & 278.6 & 235.3 & 228.60 & 1.03 \\
\hline 300 & 150 & 10.7 & 7.1 & 4000 & 278.6 & 147.8 & 142.93 & 1.03 \\
\hline 300 & 150 & 10.7 & 7.1 & 5000 & 278.6 & 105.6 & 102.07 & 1.03 \\
\hline 300 & 150 & 10.7 & 7.1 & 6000 & 278.6 & 81.6 & 78.95 & 1.03 \\
\hline 300 & 150 & 10.7 & 7.1 & 7000 & 278.6 & 66.1 & 64.30 & 1.03 \\
\hline 300 & 150 & 10.7 & 7.1 & 8000 & 278.6 & 55.8 & 54.27 & 1.03 \\
\hline 300 & 150 & 10.7 & 7.1 & 9000 & 278.6 & 48.1 & 46.99 & 1.02 \\
\hline 300 & 150 & 10.7 & 7.1 & 10000 & 278.6 & 42.4 & 41.46 & 1.02 \\
\hline \multicolumn{8}{|c|}{ Mean } \\
\hline \multicolumn{10}{|c|}{ Stander dev. } \\
\hline
\end{tabular}

Table 2: Comparison between finite element and theoretical buckling moments for castellated hexagonal beams

\begin{tabular}{|c|c|c|c|c|c|c|c|c|c|c|}
\hline $\begin{array}{c}\mathrm{b}_{\mathrm{f}} \\
{[\mathrm{mm}]}\end{array}$ & $\begin{array}{c}\mathrm{t}_{\mathrm{f}} \\
{[\mathrm{mm}]}\end{array}$ & $\begin{array}{c}\mathrm{t}_{\mathrm{w}} \\
{[\mathrm{mm}]}\end{array}$ & $\begin{array}{c}\mathrm{L} \\
{[\mathrm{mm}]}\end{array}$ & $\begin{array}{c}\mathrm{H}_{\text {Cast. }} \\
{[\mathrm{mm}]}\end{array}$ & $\begin{array}{c}\mathrm{h}_{\text {wcast }} \\
{[\mathrm{mm}]}\end{array}$ & $\begin{array}{c}\mathrm{b}_{4} \\
{[\mathrm{~mm}]}\end{array}$ & $\frac{\mathrm{b}_{4}}{\mathrm{~h}_{\text {wcast }}}$ & $\begin{array}{c}\mathrm{M}_{\text {cr-FE }} \\
{[\mathrm{kN} . \mathrm{m}]}\end{array}$ & $\begin{array}{c}\mathrm{M}_{\text {o-cr }} \\
{[\mathrm{kN} . \mathrm{m}]}\end{array}$ & $\mathrm{M}_{\text {cr-FE}} / \mathrm{M}_{\text {o-cr }}$ \\
\hline 150 & 10.7 & 7.1 & 2000 & 341.8 & 320.4 & 320.4 & 1 & 523.5 & 525.37 & 1.00 \\
\hline 150 & 10.7 & 7.1 & 3000 & 341.8 & 320.4 & 320.4 & 1 & 254.1 & 251.05 & 1.01 \\
\hline 150 & 10.7 & 7.1 & 4000 & 341.8 & 320.4 & 320.4 & 1 & 157.1 & 153.98 & 1.02 \\
\hline 150 & 10.7 & 7.1 & 5000 & 341.8 & 320.4 & 320.4 & 1 & 110.7 & 108.15 & 1.02 \\
\hline 150 & 10.7 & 7.1 & 6000 & 341.8 & 320.4 & 320.4 & 1 & 84.7 & 82.52 & 1.03 \\
\hline 150 & 10.7 & 7.1 & 7000 & 341.8 & 320.4 & 320.4 & 1 & 68.3 & 66.50 & 1.03 \\
\hline 150 & 10.7 & 7.1 & 8000 & 341.8 & 320.4 & 320.4 & 1 & 57.1 & 55.65 & 1.03 \\
\hline 150 & 10.7 & 7.1 & 9000 & 341.8 & 320.4 & 320.4 & 1 & 49.1 & 47.86 & 1.03 \\
\hline 150 & 10.7 & 7.1 & 10000 & 341.8 & 320.4 & 320.4 & 1 & 43.1 & 42.01 & 1.03 \\
\hline \multicolumn{10}{|c|}{ Stander dev. } \\
\hline \multicolumn{10}{|c|}{} \\
\hline
\end{tabular}




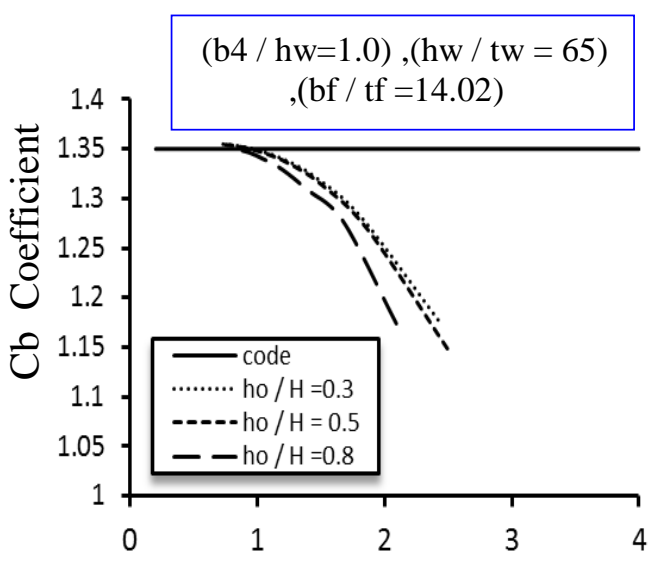

(a) $\alpha_{L B}$ Parameter

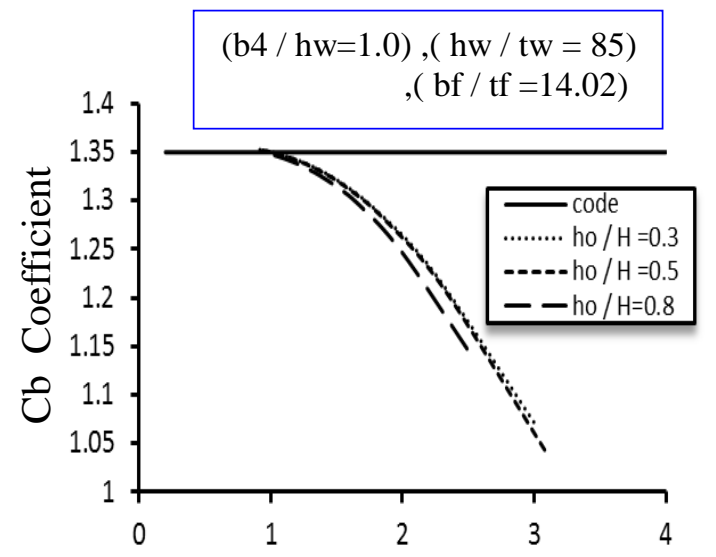

(b) $\quad \alpha_{L B}$ Parameter

Figs. 2: Variation of the $\mathrm{C}_{\mathrm{b}}$ coefficient with the $\alpha_{L B}$ parameter for Castellated steel beams

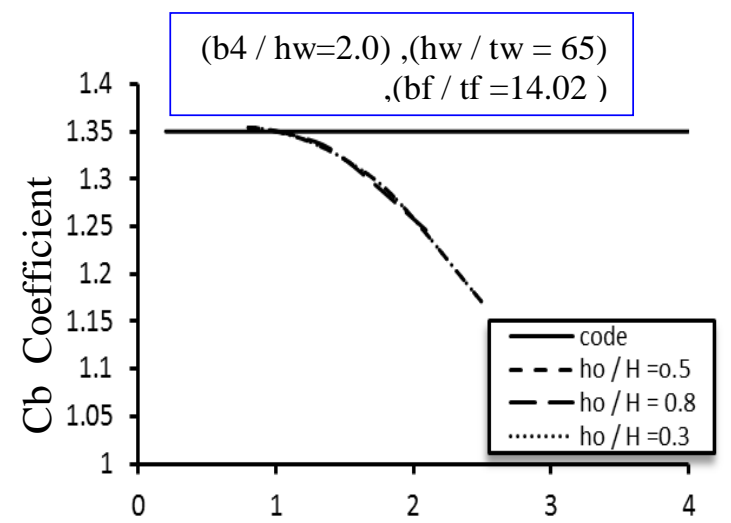

(a) $\alpha_{L B}$ Parameter

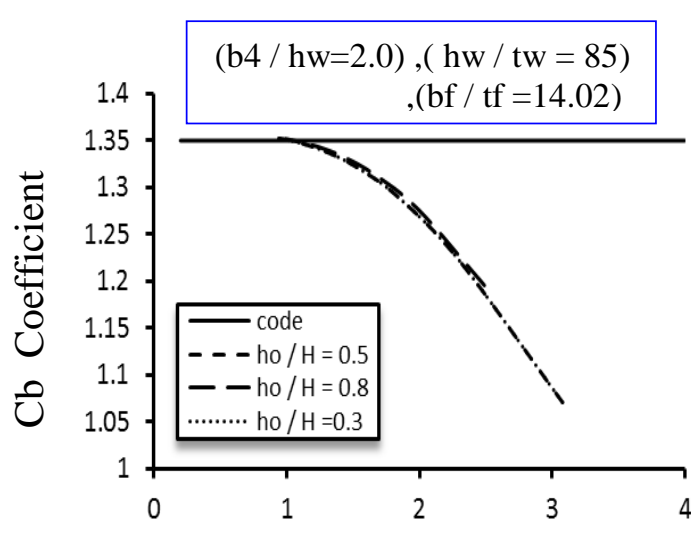

(b) $\alpha_{L B}$ Parameter

Figs. 3: Variation of the $\mathrm{C}_{\mathrm{b}}$ coefficient with the $\alpha_{L B}$ parameter for castellated steel beams
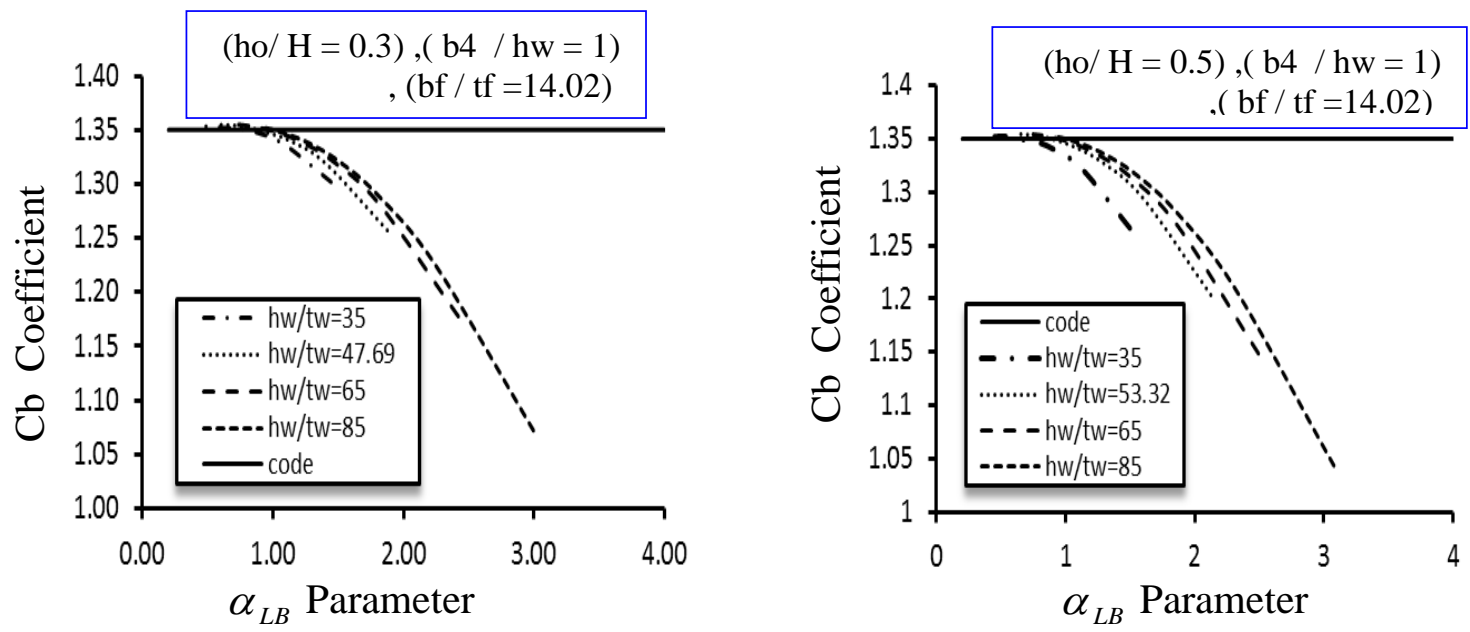

Fig. 4: Variation of the $\mathrm{C}_{\mathrm{b}}$ coefficient with the $\alpha_{L B}$ parameter for castellated steel beams 

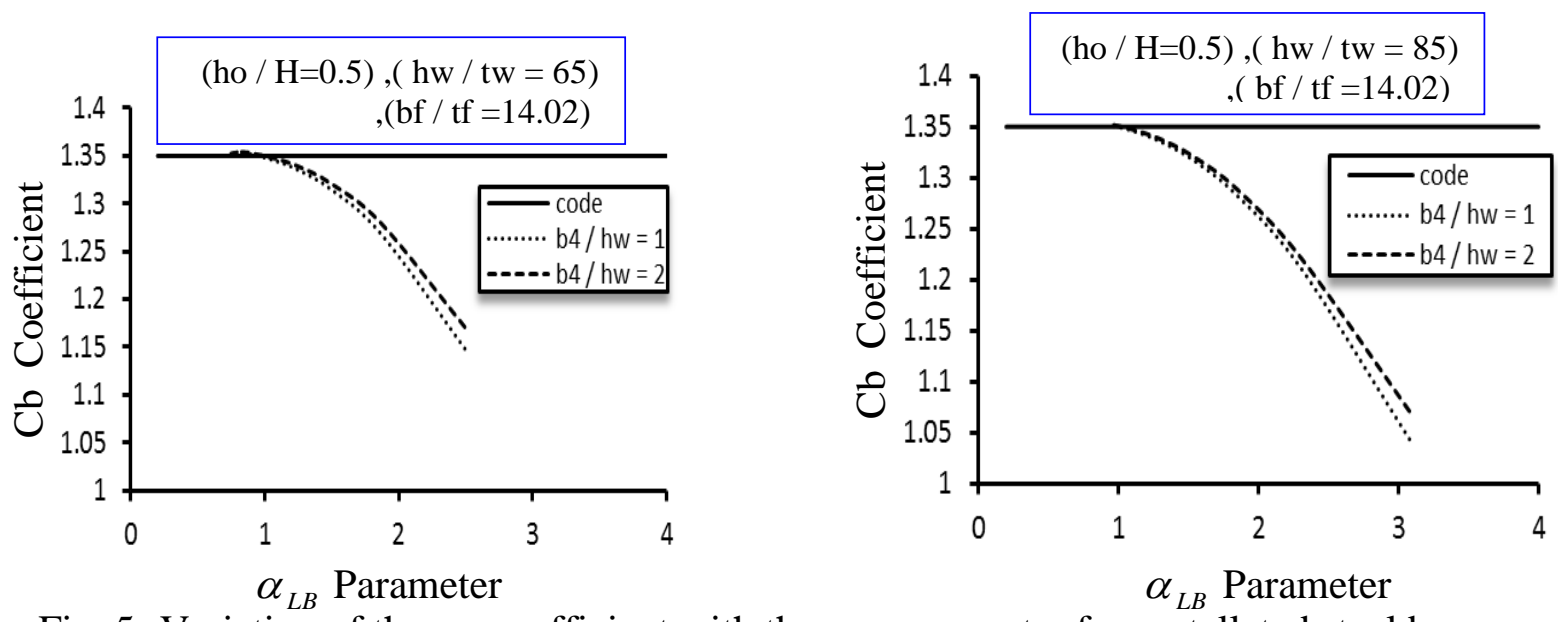

Fig. 5: Variation of the $\mathrm{C}_{\mathrm{b}}$ coefficient with the $\alpha_{L B}$ parameter for castellated steel beams
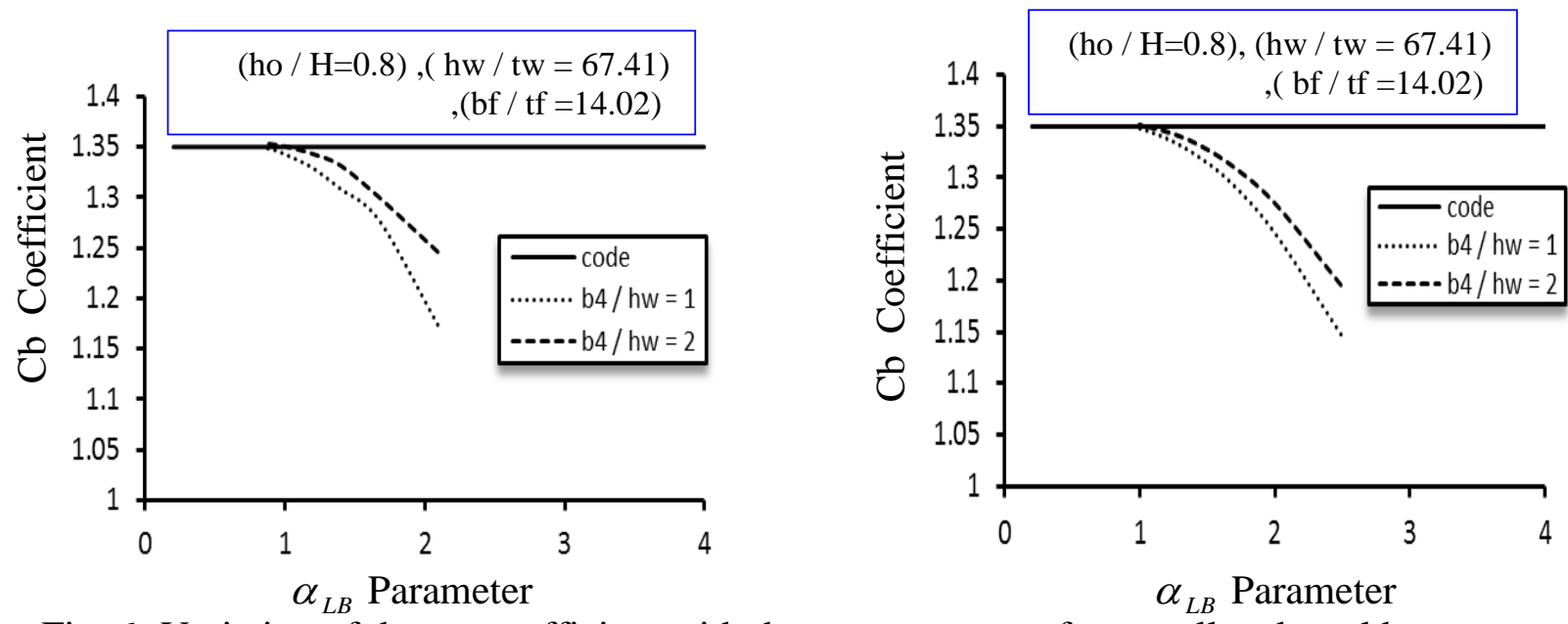

Fig. 6: Variation of the $\mathrm{C}_{\mathrm{b}}$ coefficient with the $\alpha_{L B}$ parameter for castellated steel beams

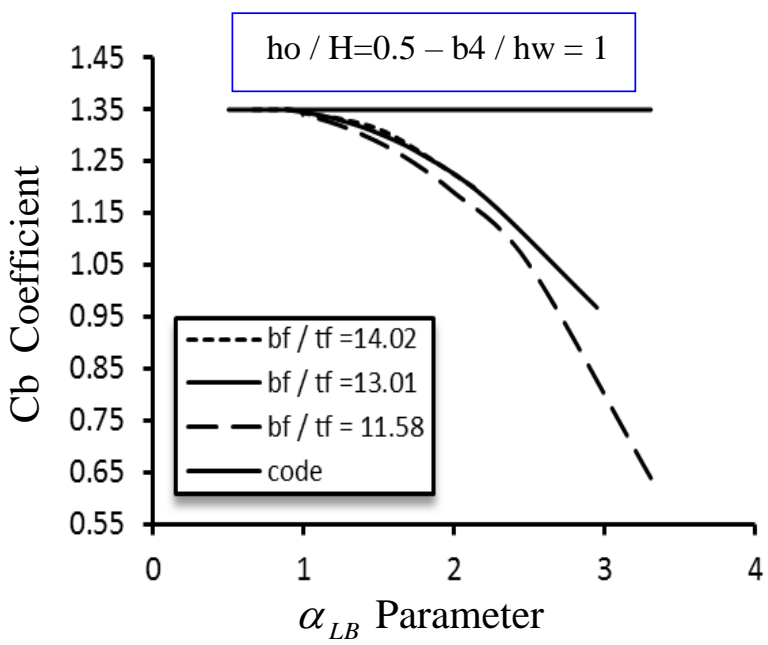

Fig. 7: Variation of the $\mathrm{C}_{\mathrm{b}}$ coefficient with the $\alpha_{L B}$ parameter for castellated steel beams 

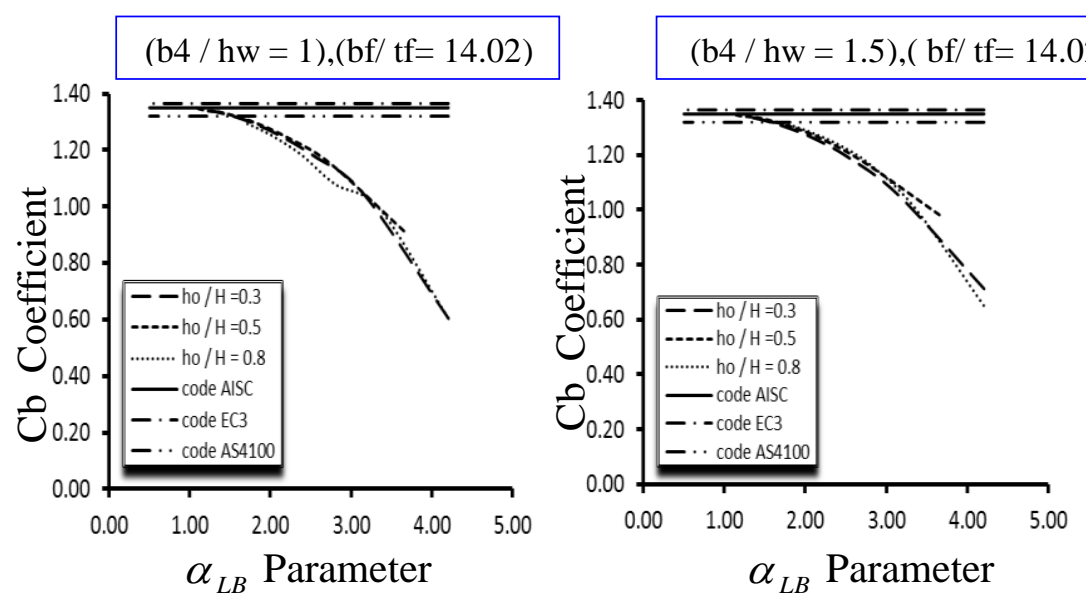

$(\mathrm{b} 4 / \mathrm{hw}=2),(\mathrm{bf} / \mathrm{tf}=14.02)$
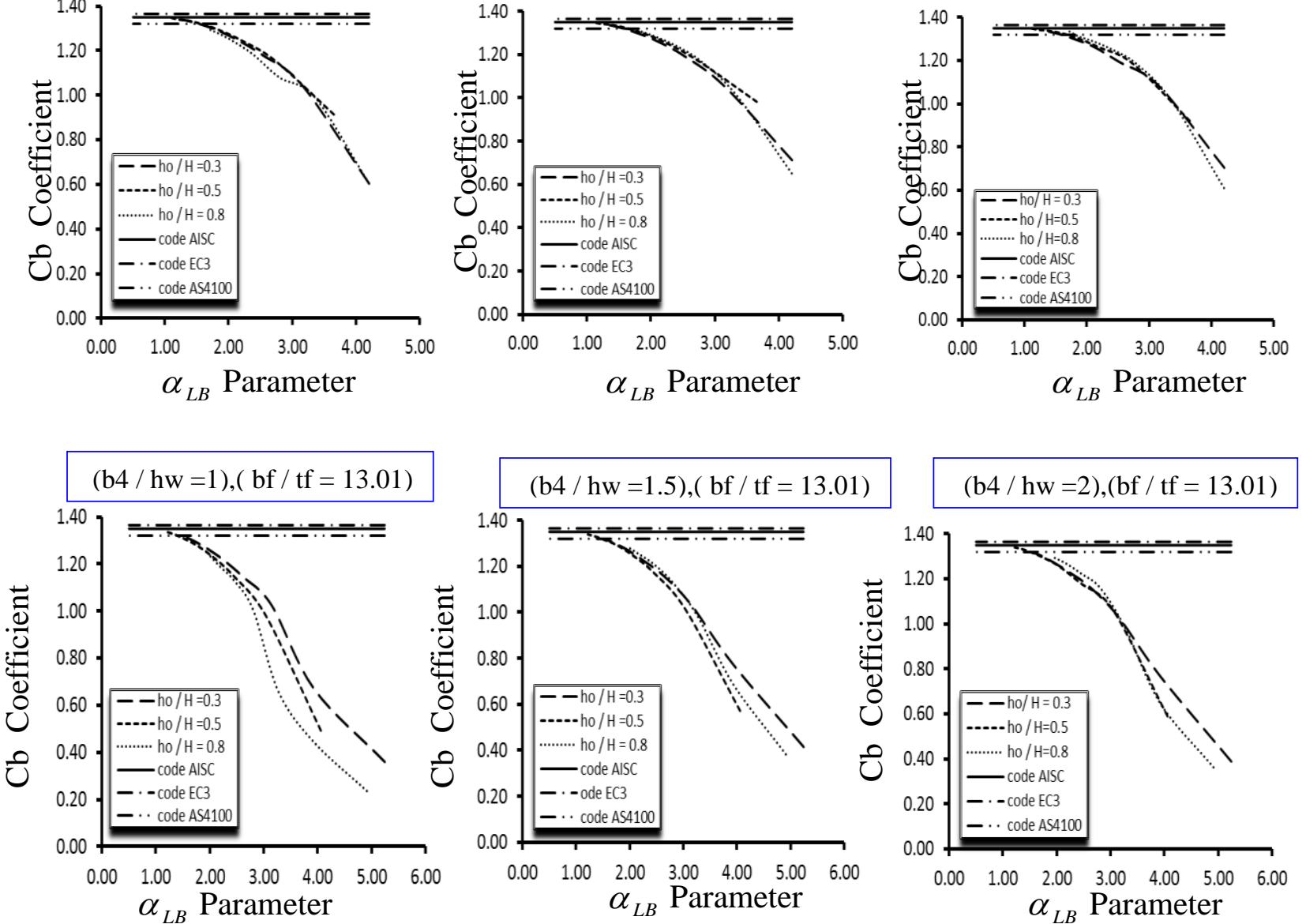

Fig. 8: Variation of the $\mathrm{C}_{\mathrm{b}}$ coefficient with the $\alpha_{L B}$ parameter for castellated steel beams
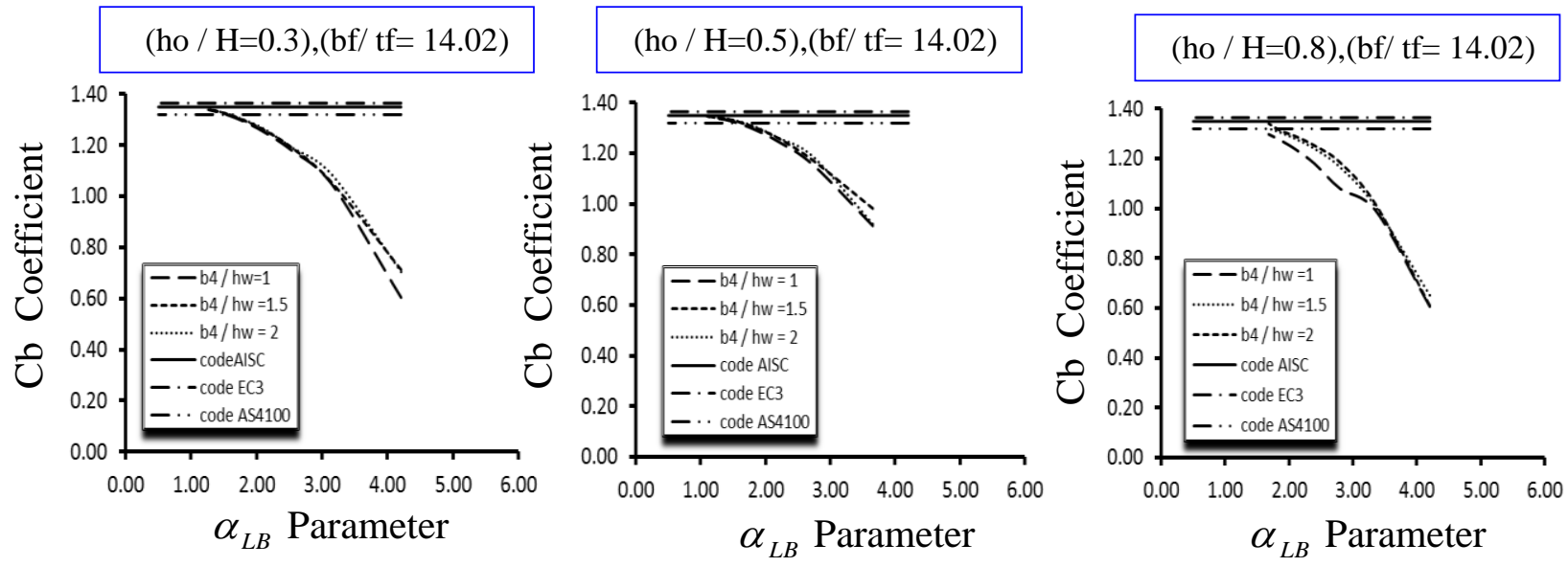

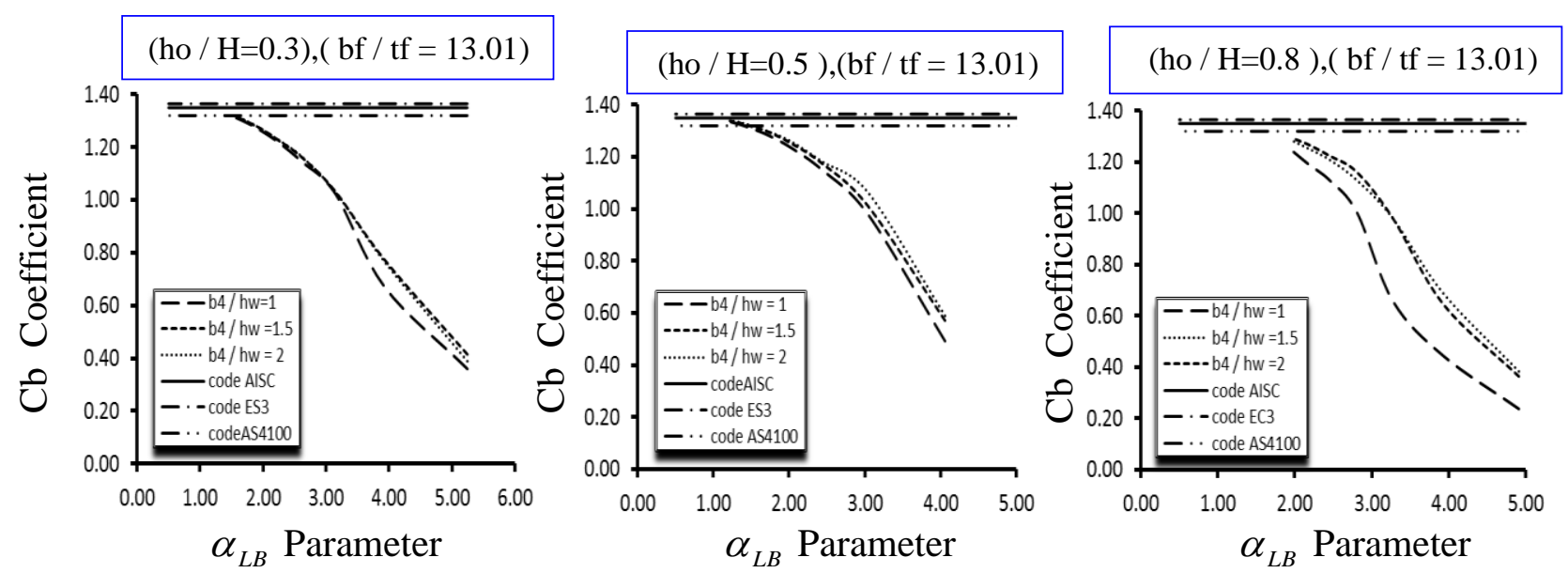

Fig. 9: Variation of the $\mathrm{C}_{\mathrm{b}}$ coefficient with the $\alpha_{L B}$ parameter for castellated steel beams

Table 3: Comparison between moment-gradient coefficient values recommended by international design codes

\begin{tabular}{|c|c|c|c|}
\hline Case of loading & $\begin{array}{c}\text { American code } \\
\text { (AISC2005 } \\
[12])\end{array}$ & $\begin{array}{c}\text { European standards } \\
\text { (EC3 [9]) }\end{array}$ & $\begin{array}{c}\text { Australian code } \\
\text { (AS4100 [11]) }\end{array}$ \\
\hline Mid-span concentrated load & 1.35 & 1.365 & 1.32 \\
\hline
\end{tabular}
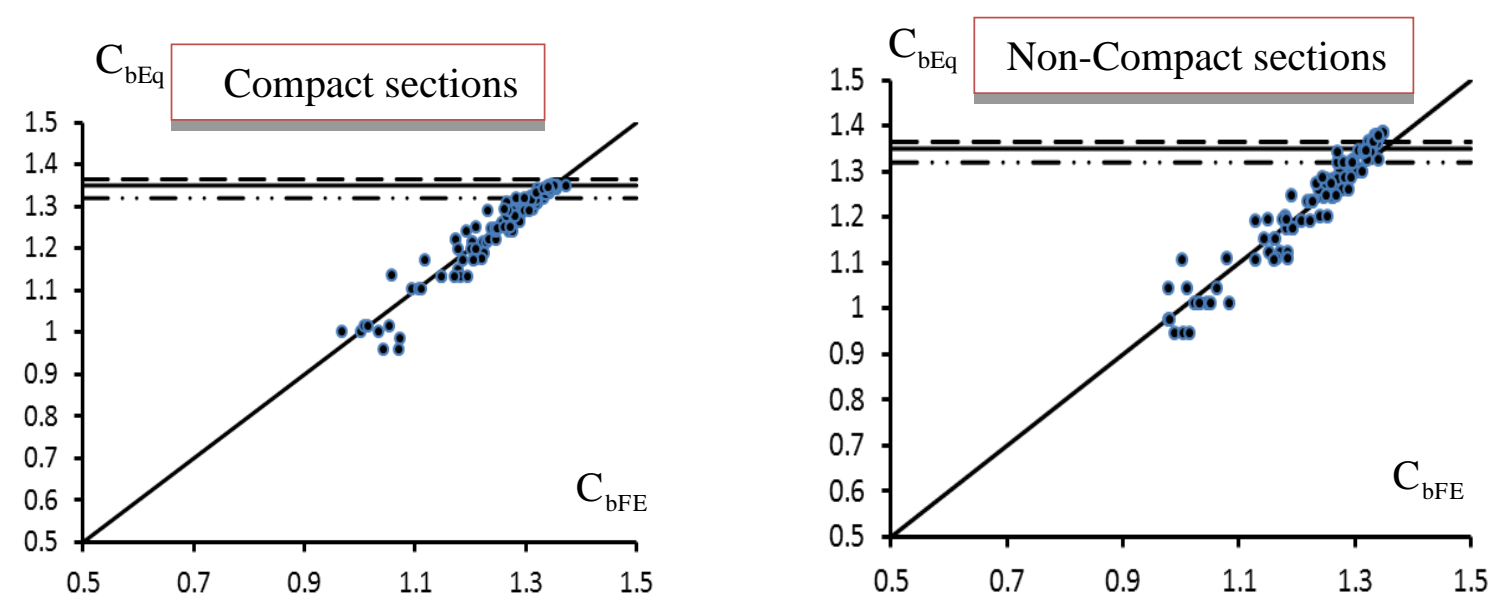

Fig.10: Variation of the $\mathrm{C}_{\mathrm{bFE}}$ coefficient with the $\mathrm{C}_{\mathrm{Eq}}$ factor for castellated steel beams

proposed equations and $\mathrm{C}_{\mathrm{b}}$ values from the FE, it can concluded that the new equations predict well the result of FE as can be seen in Fig. 10. It can be concluded that the proposed equations have good agreement compared with the FE results.

$C_{b}=-0.07\left(\alpha_{L B}\right)^{2}+0.11\left(\alpha_{L B}\right)+1.3$

(for compact section)
$C_{b}=-0.05\left(\alpha_{L B}\right)^{2}+0.05\left(\alpha_{L B}\right)+1.4$

(for non-compact section)

Where $\alpha_{L B}$ was given in Eq. 11

It can be seen that for compact and noncompact section the results of $\mathrm{C}_{\mathrm{b}}$ in the short span have lower values than codes which defined in Table 3. 


\section{Conclusions}

The current study investigated the elastic lateral buckling of simply supported castellated steel beams under mid-span concentrated loads. The study is conducted numerically using 3D FE model using ABAQUS software program. Variation of $\mathrm{C}_{\mathrm{b}}$ coefficient is investigated relative to $\alpha_{L B}$ parameter that relates the warping rigidity to the torsional rigidity of castellated steel beams. The main conclusions that may be extracted from the study are as follows.

- From the results it can be concluded that, by increasing the values of $\alpha_{L B}$ the $\mathrm{C}_{\mathrm{b}}$ values decreases. Also, the values of $\mathrm{C}_{\mathrm{b}}$ decrease with increasing the opening size.

- Increasing of the spacing of opening to the value of $\left(b_{4} / h_{w}=2\right)$ has no effect for different hole size on the reduction of $\mathrm{C}_{\mathrm{b}}$.

- For all hole size the value of $\mathrm{C}_{\mathrm{b}}$ increases with increasing the value of $\left(\mathrm{h}_{\mathrm{w}} / \mathrm{t}_{\mathrm{w}}\right)$.

- For the compact sections it was found that the values of $\mathrm{C}_{\mathrm{b}}$ were different from the predicted code. The same observation was obtained for the noncompact sections. Hence, in this section two simplified new equations were suggested for the compact sections and non-compact sections with respect $\alpha_{L B}$ parameter as a variable function. By comparing the results of $\mathrm{C}_{\mathrm{b}}$ from the proposed equations and the corresponding values from the FE, it can conclude that the new equations predict well the result of FE. Finally, it can be seen that the predicted equations have good agreement compared with the FE results.

\section{Notations:}

$\mathrm{H}$ Overall height of castellated beam

$b_{f}$ Overall flange width of castellated beam

$b_{1}$ The horizontal projection dimension of the inclined part of opening

$\mathrm{b}_{2}$ The horizontal dimension part of castellated opening

$\mathrm{b}_{3}$ The clear distance between castellated opening

$\mathrm{b}_{4}$ The distance between C.L of C.L of castellated opening

E Young`s modulus of steel

$F_{y}$ Yield stress of steel

$\mathrm{F}_{\mathrm{u}} \quad$ Ultimate stress of steel

$h_{1} \quad$ Half clear depth of castellated opening length of castellated beam

$t_{w} \quad$ Web thickness of specimen

$t_{f} \quad$ Flange thickness of specimen

$d_{f}$ The clear distance between upper flange and castellated opening

ho depth of opening

REFERENCES

[1] Zirakian, T., and Showkati, H., "Distortional Buckling of Castellated Beams ", Journal of Constructional Steel Research, Vol. 62, pp. 863-871, 2006 [2] Hosain, M.U., and Speirs, W.G., "Experiments on Castellated Steel Beams ",Supplement to the Welding Journal, Vol. August, pp. 329s-342s, 1973

[3] Showkati, H., Ghazijahani, T.G., Noori, A., and Zirakian, T., "Experiments on Elastically braced Castellated Beams ", ", Journal of Constructional Steel Research , Vol. 77, pp. 163-172, 2012

[4] Ellobody, E., "Interaction of Buckling modes in Castellated Steel Beams ", Journal of Constructional Steel Research, Vol. 67, pp. 814-825, 2011 
[5] Soltani, M. R., Bouchair, A., and Mimoune, M., "Nonlinear FE analysis of the Ultimate behavior of Steel Castellated Beams ", Journal of Constructional Steel Research, Vol. 70, pp. 101-114, 2012

[6] Mohebkhaah, A., "The Moment gradient factor in Lateral torsional Buckling on Inelastic Castellated Beams ", Journal of Constructional Steel Research , Vol. 60, pp. 1481-1494, 2004

[7] Sweedan. A., "Elastic lateral stability of I-shaped cellular steel beams", Journal of Constructional Steel Research, Vol. 67, pp. 151-163, 2011

[8] ABAQUS Standard User's Manual The Abaqus Software is a product of Dassault Systèmes Simulia Corp., Providence, RI, USA Dassault Systèmes, Version 6.8, USA, 2008
[9] ENV 1993-1-1 Eurocode 3: Design of steel structures-Part 1-1: general rules and rules for buildings, 1992, and amendment A2 of Eurocode 3: Annex N 'Openings in Webs'. British Standards Institution; 1998.

[10] Timoshenko SP, Gere JM. Theory of elastic stability. 2nd ed. New York (NY):

McGraw-Hill Book Company; 1961

[11] Standards Australia (SA). AS 4100 Steel Structures. Sydney (Australia); 1998 [12] American Institute of Steel Construction (AISC). ANSI/AISC 360-05 specification for structural buildings. 13th ed. Chicago (USA); 2005 